\title{
К.А. Торжевский
}

\section{КРИПТОВАЛЮТА КАК ИНСТИТУТ ЦИФРОВОЙ ЭКОНОМИКИ}

\begin{abstract}
В статье рассматривается роль криптовалюты (и в частности биткоина - ВТС) в процессе перехода к информационному обществу и цифровой экономике через призму трансформации социально-экономических институтов. Анализируется влияние ВТС на основные институты общественного развития: института денежного обращения, посреднический, трансмиссионный, накопительный и др. Показана значимость блокчейна, как одной из передовых IT-технологий, появившихся вместе с ВТС.

Ключевые слова: криптовалюта, биткоин, блокчейн, социально-экономические институты.

JEL классификация: E40, E50, G20.
\end{abstract}

Криптовалюта - относительно новый атрибут современного информационного общества. Начало криптовалюте положил выпуск биткоина (ВТС) весной 2008 г. Создателем ВТС считается Сатоши Накамото - американский хакер японского происхождения [1]. О его личности мало что известно, поскольку после выпуска первого пакета ВТС он исчез из горизонта. В связи с этим существует версия, что Сатоши Накамото - это псевдоним, под которым скрывается другая личность (возможно, другой хакер - Ник Сабо) или даже целая группа людей. Но если Сатоши Накамото - это реальная личность, то в настоящее время он является одним из богатейших людей мира, долларовым миллиардером, поскольку курс ИЕС за десять лет вырос в миллионы раз.

Первоначальный курс ВТС был чрезвычайно низким: 1 ВТС $\approx 0,075$ цента; на 10 тыс. ВТС в этот период можно было купить 2 пиццы «Папа Джонс» (такая сделка действительно имела место и была признана одной из наиболее крупных) [2]. Если инвестор приобрел на стартовом периоде 10 ВТС и сохранил их, то на дату 04.2018 г. его состояние выросло до 68410 долл.

Отношение к ВТС в разных странах мира различно. Условно его можно представить как: 1) либеральное (США); 2) нейтрально-настороженное (Россия); 3) негативно-запретительное, закрепленное в жестких правовых документах (Китай). Однако общий тренд: медленный дрейф в сторону более либерального отношения к ВТС. В значительной степени это обусловлено, с одной стороны, жизнеспособностью ВТС (которую он доказал своим фактом существования в течение 10 лет); с другой стороны - той его особенностью, что ВТС фактически нельзя запретить (нельзя запретить общение людей через виртуальные сети); с третьей - тем, что он перестал быть уникальным общественным феноменом: его функционирование подкреплено появлением множества видов других криптовалют, действующих на схожих принципах (их сейчас насчитывается около 3 тыс. [3]; с четвертой - тем, что очень большое число инвесторов (особенно молодежи) работает на криптовалютном сегменте финансового рынка. Часть из них легально или полулегально занимается майнингом (англ. - добычей) ВТС согласно протоколу, другая является игроками на курсе этой валюты. 
В настоящее время стало очевидным, что появление ВТС было событием, которое нельзя иначе оценить как мощный прорыв в общественной жизни, уже сейчас особенно заметный в сфере IT-технологий и финансовом секторе экономики. Независимо от того, как к этому событию относятся правительства различных стран, его роль можно сравнить разве что с появлением Интернета, коренным образом изменившего весь жизненный уклад общества и социально-производственные взаимодействия экономических агентов.

По выражению Алекса Форка, издавшего первую русскоязычную книгу о ВТС [4], «биткоин - больше, чем деньги»; это еще и технология блокчейна (цепочки блоков), впервые разработанная для ВТС и включенная в его протокол. Возможности ВТС таковы, что он оказывает существенное влияние на наиболее важные институты общественного развития, а в будущем его влияние только усилится.

В том числе, его влияние распространяется на:

- социально-экономические институты, путем поддержки принципов демократизации бизнеса (в сети ВТС отсутствует «порог» вхождения в рынок, инвестиция может быть сколь угодно минимальной); развитие принципов приватности как в личной жизни, так и в предпринимательстве (обязательное условие анонимности трансакций, «деньги любят тишину»); исключение возможности директивных воздействий на сделки со стороны управляющих структур и т.д.;

- финансовые институты, трансформируя систему денежного обращения по принципу распределенных (так называемых пиринговых) сетей; ограничивается и реорганизуется, (а, возможно, упраздняется) кредитная деятельность банков; эмиссия денег осуществляется внутри пиринговой сети, тем самым ликвидируется государственный сеньераж; исключается возможность «включения печатного станка» и т.д. На эти преимущества децентрализованной денежной системы указывал в свое время нобелевский лауреат Фридрих Август фон Хайек в своей работе «Частные деньги» ${ }^{1}$ [5]. Главным преимуществом он считал отсутствие возможности «порчи денег» в интересах финансового истеблишмента. И хотя в свое время его идея считалась маргинальной (как, впрочем, и сейчас ее оценивают многие аналитики) впоследствии она обрела сторонников. В частности, ее поддержал другой нобелевский лауреат - Милтон Фридман [7];

- трансмиссионный институт взаимодействия экономических агентов ускоряется работа механизма экономических транзакций вследствие увеличения скорости информационного обмена, расширения числа возможных вариантов принятия решений и количества потенциальных участников экономических контрактов. В результате увеличивается эффективность принимаемых решений, активизируется бизнес, создаются предпосылки для экономического роста;

1 В оригинале - денационализированные деньги [6]. 
- посреднический институт. Поскольку концепция ВТС основана на создании цепочки прямых связей и отмене посредников, по мере развития сети ВТС устраняются (в предельном случае - упраздняются) посреднические услуги, так как цена на проведение транзакций в системе ВТС ничтожно мала, резко снижается стоимость взаимодействия экономических агентов. Уменьшение стоимости транзакций - еще один важный аспект роли ВТС в трансформации общественно-экономических отношений и народнохозяйственный эффект от его использования. Причем это касается не только финансового сектора и изменения условий функционирования банковской системы (как одного из разновидности финансового посредничества), но и реального сектора экономики. Здесь, также как и в процессе видоизменения трансмиссионного института, большую роль должна сыграть технология блокчейна [8]. Мелани Свон, основатель Института исследования технологии блокчейна (Institute for Blockchen Studies), классифицирует сферы применения блокчейна на три категории [9]:

1) блокчейн в финансовой сфере, как криптовалюта, и в первую очередь, как ВТС, разработанный Сатоши Накамото;

2) блокчейн в реальной экономике; это прежде всего различные так называемые смарт-контракты, условия которых формулируются в терминах блокчейна таким образом, что невыполнение контрактных условий оказывается невозможным или крайне не выгодным;

3) блокчейн в сфере государственного управления, культуры, здравоохранения (обработка и хранение данных, имеющих реестровую природу). Так как в каждой транзакции сети ВТС записывается история всех предшествующих операций, отпадает необходимость в бухгалтерском контроле и учете. В этом смысле ВТС - это электронная бухгалтерская книга. Поскольку все три сферы (финансовая, реальная и управление) предполагают единую IT-платформу, становится очевидным целесообразность выбора ВТС в качестве валюты для денежного обращения;

- институт накопления на всех уровнях общественно-экономической системы: личные сбережения и бюджет домашних хозяйств, фонды развития фирм и организаций и т.д. Вложение в ВТС (или иную криптовалюту) является хотя и рисковым, но достаточно эффективным инструментом роста накоплений, о чем свидетельствует быстрый рост состояний инвесторов, вложившихся в ВТС. В таблице 1 приведен список состояний, сформировавшихся за короткий срок только лишь на основе инвестиций в ВТС. Принцип анонимности, используемый в криптовалютных системах, исключает возможность получения достоверных данных; имеется возможность анализа лишь той информации, которая находится в открытом доступе (например, по заявлениям самих владельцев состояния). Хотя список не полный (долларовых мультимиллионеров гораздо больше!), но он все равно впечатляет. Чего стоит только история подростка Эрика Финмана, ставшего миллионером в 15 лет! Крутой поворот судьбы был и у братьев-близнецов Тэйлора и Кэмерона Уинклвосс - первых миллиардеров, заработавших свое состояние на ВТС. Источник их миллиардов - средства, получен- 
ные ими как отступные в результате мирового соглашения по судебному процессу с М. Цукербергом и вложенные в ВТС.

Не обходят своим вниманием и многие селебритиз - Майк Тайсон, актеры Эштон Катчер, Хью Лори («Доктор Хаус»), Гвирет Пэлтроу и др.

Таким образом, многие западные бизнесмены активно и успешно функционируют на рынке криптовалюты, в то время как в России продолжаются дискуссии по проблемам оценки рисков, связанных с ее обращением, ее правовой регламентацией и перспективами развития [11-14].

\section{Таблица 1}

\section{Состояния, заработанные благодаря инвестициям в ВТС}

\begin{tabular}{l|c}
\hline \multicolumn{1}{c|}{ Фамилия, Имя, Отчество } & $\begin{array}{c}\text { Величина состояния, } \\
\text { млрд долл. }\end{array}$ \\
\hline 1. Крис Ларсен & 20 \\
2. Братья Тэйлор и Кэмерон Уинклвосс & 10 \\
3. Сатоши Накамото & 6,8 \\
4. Роджер Вер & 2 \\
5. Чарли Шрем & 680 \\
6. Энтони Галлипи & 230 \\
7. Джерад Кена & 30 \\
8. Эрик Финман & 2,7 \\
\hline
\end{tabular}

Источник: [10].

Вывод: Проведенный анализ криптовалюты как института цифровой экономики свидетельствует о том, что ее появление и функционирование приводит к постепенной глубинной трансформации общественной жизни через модификацию или устранение старых и появлению новых социально-экономических институтов, соответствующих требованиям цифровой экономики. И этот процесс становится необратимым.

\section{СПИСОК ЛИТЕРАТУРЫ}

Nakamoto S. Bitcoin: A Peer - to Peer Electronic Cash System, 2008 // Bitcoin. URL: https://bitcoin.orp/bitcoin.pdf

Mack E. The Bitcoin Pizza Purchase That's Worth \$7 Million Today // Forbes, 2013, December 23.

Глобальный финансовый портал investing.com. URL: http://www.Август2019

Форк А. Биткоин: больше чем деньги. Продюсерский центр Александра Гриценко, 2014.

Хайек Ф.А. Частные деньги. - М.: Институт национальной модели экономики, 1966.

Hayek F.A. von. Denationalization of money. An analysis of the Theory and Practice of Concurrent Currencies. London, Institute of Economic Affairs, 1976.

Friedman M., Schwartz A.J. Has government any role in money? // Journal of Monetary Economics. 1986. Vol. 17. Iss. 1, January. P. 37-62/

Филькин М.Е. Технология блокчейн и уровни ее применимости. М.: Вестник ЦЭМИ РАН, 2019, вып. 1.

Свон М. Блокчейн: схема новой экономики // М.: Олимп-бизнес, 2017.

https://tehoobzor.com/criptolife/bitcoin/2342-bitcoin.miiionery-kto-razbogatel-na-kriptovalyute.htm

Кутырин А.Г., Волеводз А.Г. Место электронных денег в системе денежных инструментов: некоторые данные к оценке рисков оборота криптовалюты и изучению проблем ее правовой ре- 
гламентации. URL: https://mgimo.ru/upload/:blok/845/05\%.20кутырин\%20B.A.\%20

Волеводз\%20А.Г.\%20-\%20.статья.pdf

Кесслер К.А. Криптовалюта как будущее мировой денежной системы // Novainfo.ru. 2015. № 35. C. $110-113$.

Егорова Н.Е., Торжевсикй К.А. Биткоин: основные закономерности и перспективы функционирования // Экономика и предпринимательство. 2015. № 3-2 (56-2). С. 334-340.

Искандирова Х.Ф., Раииякая Ю.С. К вопросу о хождении криптовалюты на территории Российской Федерации // Современные тенденции развития науки и технологий. 2015. № 6-8. С. 48-50.

\section{Torzhevsky K.A.}

\section{CRYPTOCURRENCY AS AN INSTITUTE OF DIGITAL ECONOMY}

The article discusses the role of cryptocurrency (and in particular Bitcoin - BTC) in the transition to the information society and digital economy through the prism of transformation of socio-economic institutions. The influence of BTC on the main institutions of social development is analyzed: the institution of money circulation, intermediary, transmission, accumulation, etc. The significance of the blockchain as one of the advanced IT technologies that appeared along with BTC is shown.

Keywords: cryptocurrency, bitcoin, blockchain, socio-economic institutions.

JEL Classification: E40, E50, G20. 